\title{
Primary vaginal melanoma in the setting of mucosal melanosis- A case report and literature review
}

\author{
Deirdre Kelly $^{1 *}$, Jack Gleeson ${ }^{1}$, Geoffrey Watson ${ }^{1}$, Graham Woods ${ }^{2}$, Conor O'Keane ${ }^{2}$ and John Mc Caffrey ${ }^{1}$ \\ ${ }^{1}$ Department of Medical Oncology, Mater Misericordiae University Hospital, Dublin, Ireland \\ ${ }^{2}$ Department of Histopathology, Mater Misericordiae University Hospital, Dublin, Ireland
}

\begin{abstract}
\section{Introduction}

Melanoma can arise from any mucosal epithelium lining including the vulvovaginal. Melanoma from this site is more likely to be multifocal and carries a worse prognosis than cutaneous melanoma. Primary Vaginal melanomas are extremely rare with an estimated incidence of $0.026 / 100,000$ women per year [1]. As a result there is limited understanding of the pathogenesis, risk factors and optimal treatments for primary vaginal melanoma.
\end{abstract}

We present a rare case of localised, biopsy proven vaginal melanoma and vaginal melanosisin a Caucasian 66 year old who presented with postmenopausal bleeding. A systematic literature review of journal articles published between December 2013 and November 2015 was performed for studies conducted in Europe and the United States of America using Medline and Pubmed. Articles were selected for review if they included large (over 10 cases)retrospective analysis, epidemiological review and genetic analysis of primary vaginal melanoma and/or primary vulvar melanoma.Our findings demonstrate the challenges of researching and treating rare diseases.

\section{Case}

A 64 year old lady presented to her GP with a six week history of postmenopausal bleeding. Her background was significant for a hysterectomy in 2001 and bilateral salpingo-oophorectomy for endometriosis. She is a social smoker. She was referred to the gynaecology service and underwent an Examination under Anaesthesia (EUS) and cystoscopy which revealed a lesion at the right side of the vaginal vault approximately $2-3 \mathrm{~cm}$ in size, which was resected. There was a small amount of residuallesional tissue present. The vulva and urethra were normal. Biopsy revealed an invasive malignant melanoma (Figure 1).

Her case was reviewed at the Gynaecological multidisciplinary meeting and she was subsequently admitted electively for a laparoscopic vaginectomy. However multiple foci of dark lesions were noted on the upper, mid posterior, left lateral and left anterior vaginal wall which were not amenable for complete excision with the planned procedure so only vaginal biopsies were taken revealing areas of vaginal melanosis and malignant melanoma in situ (Figures 2 and 3). PET CT revealed no evidence of distant disease. Her case was discussed at the Oncology MDM and the decision was made to proceed to vaginectomy with radiation if the surgical margins were positive.

\section{Discussion}

Vaginal melanoma has five-year survival rates ofbetween 5-20\% [2]. The aetiology is poorly understood .Several risk factors have been implicated,including; chronic inflammatory disease, viral infections and chemical irritants [3]. The majority of patients will develop metastatic disease regardless of treatment intervention. Several different modalities have been used; extensive surgical resection versus conservative excision and radiation [4]. It is unclear if there is any additional survival gain from lymphadenectomy $[5,6]$. In the metastatic setting primary vaginal melanoma has limited response to cytotoxic regimens. Platinum /taxanes have been used with response rates up to $20 \%$ [7].Ipilimumaband vemurafenib are approved for use despite the fact that there were no trials in this setting as data was extrapolated from trials done in cutaneous melanoma [7].

Microscopically, most vaginal malignant melanomas contain sheets of cells which vary from bland to very irregular and are not indicative of any common type of vaginal cancer [8]. Prognostic factors are debated (8), however a recent study showed mitotic count and lymph node status were the most important histological prognostic factors for disease free survival [9]. Mucosal melanosis, of which genital and specifically vaginal melanosis is a type, is a benign lesion which can mimic melanoma clinically [10-12]. They can however be

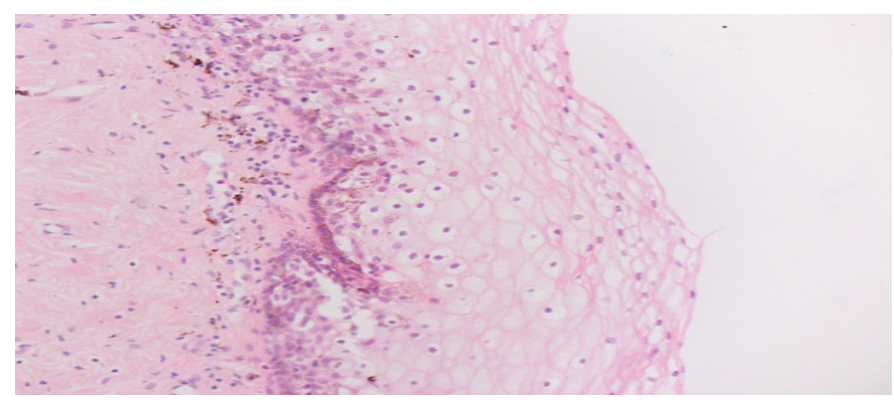

Figure 1.H\&E, Original Magnification 400X. Vaginal Biopsy (first procedure) Multiple fragments of high grade malignant tumour with large areas of necrosis. Immunohistochemistry showed tumour cells to be MelanA, HMB45 and S100 positive as well as focally $\mathrm{p} 53$ positive. The findings are consistent with invasive malignant melanoma.

Correspondence to: Deirdre Kelly, Departments of Medical Oncology, Mater Misericordiae University Hospital, Eccles St., Dublin 7, Ireland, Tel:0860706237, E-mail: deirdrekelly@mater.ie

Received: April 15 2016; Accepted: May 03, 2016; Published: May 07, 2016 
Table 1. Literature Review of Case Series between of Primary Vaginal and Vulvar Melanoma 2013-2015.

\begin{tabular}{|c|c|c|c|}
\hline Reference & Study Type & Patient Population & Results \\
\hline$[7]$ & Case Series & $\begin{array}{l}15 \text { vulvar melanoma } \\
5 \text { vaginal melanoma }\end{array}$ & $\begin{array}{l}\text { Vulvar } \\
\text { BRAF mutation } 7.6 \% \\
\text { C-KITmutation } 27.6 \% \\
\text { NRAS mutation } 27.6 \% \\
\text { Vaginal } \\
1 \text { TP53 mutation } 7\end{array}$ \\
\hline$[20]$ & Retrospective analysis & $\begin{array}{l}14 \text { vaginal melanoma } \\
4 \text { cervical melanomas } \\
5 \text { urethral melanomas } \\
1 \text { vulvar melanoma. }\end{array}$ & $\begin{array}{l}\text { NRAS mutations }(4 / 24,21 \%) \\
\text { KIT mutations }(1 / 24,4 \%) \\
\text { BRAF mutations absent } \\
\text { 3/4 NRAS mutations were in vaginal melanomas }(21 \%) \\
\text { mainly affecting codon } 61 \\
1 \text { KIT mutation was in a vaginal melanoma effecting exon } 17\end{array}$ \\
\hline [3] & Retrospective analysis & 44 vaginal melanoma & $\begin{array}{l}\text { median follow-up } 18.9 \text { months } \\
68.2 \% \text { recurrences } \\
21(47.7 \%) \text { died of disease } \\
\text { Median PFS } 14.4 \text { months } \\
\text { median OS } 39.5 \text { month } \\
\text { Depth of invasion associated with OS }(\mathrm{P}=0.023)\end{array}$ \\
\hline [4] & Case Series & $\begin{array}{l}31 \text { vaginal melanoma } \\
\text { median age } 58 \text { years } \\
22 \text { surgery } \\
7 \text { chemotherapy } \\
19 \text { immunotherapy }\end{array}$ & $\begin{array}{l}\text { median follow-up } 20.2 \text { months } \\
\text { 5-year OS } 32.3 \% \text {. }\end{array}$ \\
\hline [21] & Epidemiological Study & $\begin{array}{l}762 \text { vulvar and vaginal melanoma } \\
28 \text { black patients }\end{array}$ & $\begin{array}{l}350(45.9 \%) \text { presented with localized disease }(\mathrm{P}<0.0001) \\
\text { median survival of black patients } 16 \text { months } \\
\text { median survival in the nonblack population was } 39 \text { months }\end{array}$ \\
\hline [5] & Retrospective analysis & $\begin{array}{l}24 \text { primary vaginal melanoma } \\
\text { Treatment } \\
42 \text { surgery } \\
9 \text { local adjuvant treatment } \\
10 \text { systemic therapy }\end{array}$ & $\begin{array}{l}\text { Median relapse-free survival was } 10.9 \text { months. } \\
\text { C-KIT-negative status }(\mathrm{P}=0.01) \text { associated with locoregional recurrence. } \\
\text { Median overall survival }(\mathrm{OS}) \text { was } 28.4 \text { months. } \\
\text { Involvement of lymph node metastasis decreased } \mathrm{OS}(\mathrm{P}<0.01) \text {. }\end{array}$ \\
\hline$[6]$ & Case series & $\begin{array}{l}36 \text { post surgery for primary vaginal } \\
\text { melanoma } \\
14 \text { post surgery for vulvar melanoma }\end{array}$ & $\begin{array}{l}5 \text {-year OS rate was } 30.9 \% \text {, with median OS of } 3.3 \text { years. } \\
\text { Vulvar melanomano improved OS }(\mathrm{p}=0.39) \\
1 \text { patient with vaginal melanoma had a partial response to carboplatin / } \\
\text { paclitaxel .After further surgical resection andadjuvant carboplatin/ } \\
\text { paclitaexlandbevacizumab is disease free at } 5 \text { years. }\end{array}$ \\
\hline
\end{tabular}

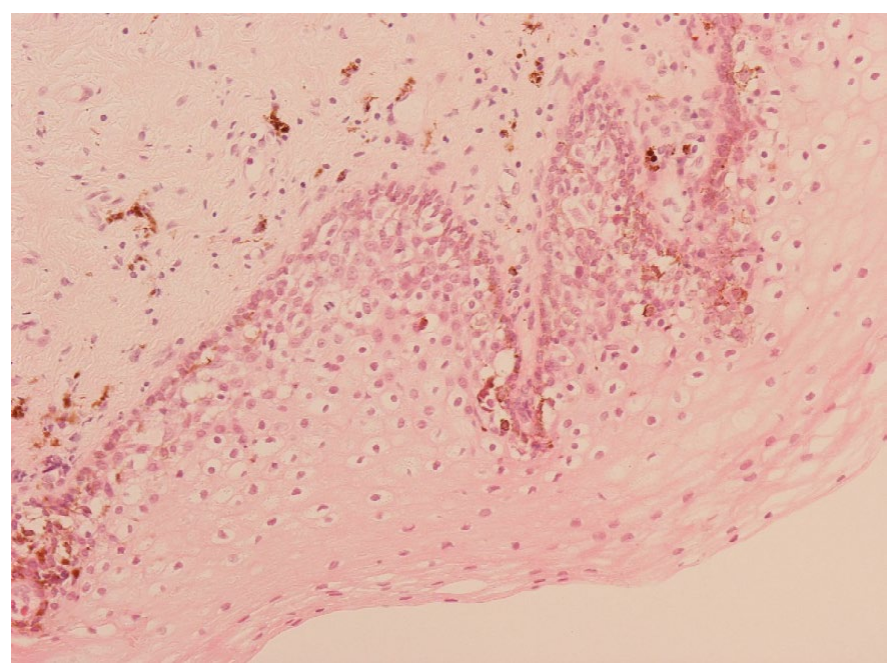

Figure 2. H\&E, Original Magnification 200X. Left anterior vagina (second procedure) Large atypical melanocytes with clear cytoplasm with mitoses are present in the lower third of the epithelium, with no invasive component identified. Subepithelial melanophages are also present. The findings are consistent with malignant melanoma in situ. Immunohistochemistry (MelanA and HMB45) was supportive of this diagnosis.

differentiated histologically [13]. Mucosal melanosis is associated with the following features; increased pigmentation of basal keratinocytes, increased melanocytes without atypia and pigment incontinence into the subepithelium[11-16]. The combination of both vaginal melanoma and vaginal melanosis in the same patient has been documented [17], however is exceptionally rare. It has been suggested that mucosal

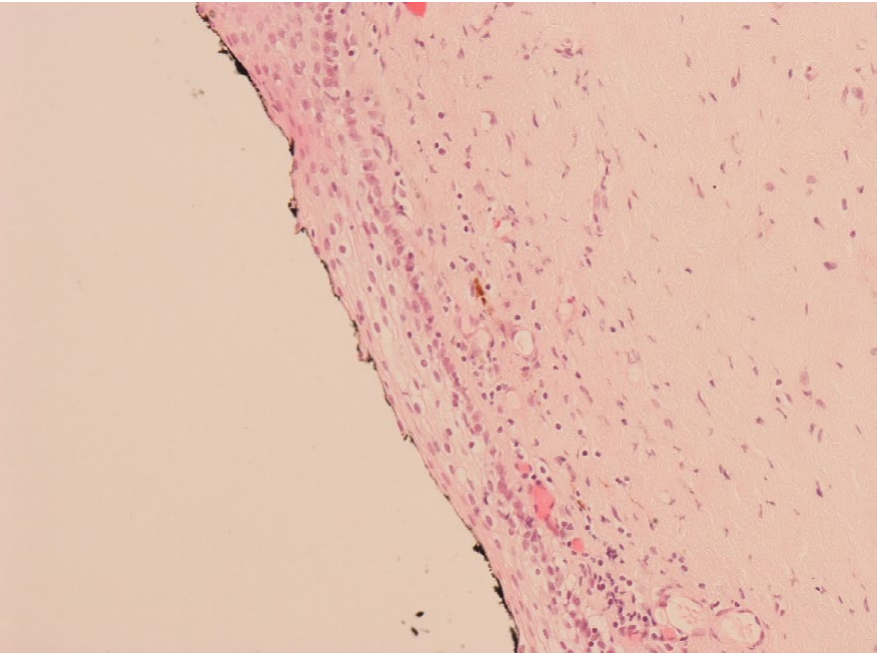

Figure 3.H\&E, Original Magnification 200X. Posterior vagina (second procedure) Increased subepithelial melanophages as well as subepithelial chronic inflammation is present. There are no atypical melanocytes present. The findings are consistent with vaginal melanosis. Immunohistochemistry (MelanA and HMB45) was supportive of this diagnosis. Note that a small amount of black surface marking ink is present.

melanosis is a possible precursor of melanoma [17], however one recent long term follow up of patients with vulvalmelanosis revealed no progression of melanosis to melanoma [18]. Overall, genital, including vaginal, melanosis is considered benign and conservative management with follow up to monitor for progression and treating this accordingly if present is the current standard of treatment $[18,19]$. 
A systematic literature review of journal articles related to vaginal and/or vulvar melanomapublished between December 2013 and November 2015 was performed for studies conducted in Europe and the United States of America (USA), using Medline and Pubmed. Articles were selected for review if they included large (over 10 cases) retrospectiveanalysis, epidemiological review, and genetic analysis of primary vaginal melanoma and/or primary vulvar melanoma (Table 1).

Six journals involving 953 patients, 336 had vaginal melanoma and 617 had vulvar melanomas. The median OS for vaginal melanoma was 39 months [2,4-6]. Two studies performed genetic analysis, which revealed; $1 / 15$ vulvar melanomas had a BRAF mutation, 4/15 had a NRAS mutation and 3/14 had a C-KIT mutation. 3/14 vaginal melanomas had an NRAS mutation[7,20]. Median survival in patients who were black was significantly reduced; 16 months versus 39 months [9].

Our results confirm the poor outcomes of vaginal and vulvar melanomas despite multiple treatment options [21]. Genetic analysis revealed differences in targetable mutations between vulvar and vaginal melanoma. This suggests that they should be studied as separate entities, and treatments should be tailored accordingly. Further study is required to understand differences in outcomes between the different targetable mutations and between black and non-black patients.

In conclusion primary vaginal melanoma, especially in the setting of mucosal melanosis, demonstrates the challenges of researching and treating rare diseases. A proportion of these tumors will harbor an activating mutation and may respond to targeted agents. The role of immunotherapy requires further assessment. Overall a collaborative treatment making process should be undertaken with quality of life and patient preference being prioritised.

\section{References}

1. Weinstock MA (1994) Malignant melanoma of the vulva and vagina in the United States: patterns of incidence and population-based estimates of survival. Am J Obstet Gynecol 171: 1225-1230. [Crossref]

2. Wechter ME, Gruber SB, Haefner HK, Lowe L, Schwartz JL, et al. (2004) Vulvar melanoma: a report of 20 cases and review of the literature. $J$ Am Acad Dermatol 50: 554-562. [Crossref]

3. Xia L, Han D, Yang W, Li J, Chuang L, Wu X (2014) Primary malignant melanoma of the vagina: a retrospective clinicopathologic study of 44 cases. Int $J$ Gynecol Cancer 24: 149-155. [Crossref]

4. Huang Q, Huang H, Wan T, Deng T, Liu J (2013) Clinical outcome of 31 patients with primary malignant melanoma of the vagina. J Gynecol Oncol 24: 330-335. [Crossref]

5. Vaysse C, Pautier P, Filleron T, Maisongrosse V (2013) A large retrospective multicenter study of vaginal melanomas: implications for new management. Melanoma Res 23: 138-146. [Crossref]

6. Markovic SN, Weaver AL, Cliby WA (2013) Vulvar and vaginal melanoma: case series and review of current management options including neoadjuvant chemotherapy. Gynecol Oncol 129: 533-537. [Crossref]

7. Rouzbahman M, Kamel-Reid S, Al Habeeb A, Butler M, Dodge J, et al. (2015) Malignant Melanoma of Vulva and Vagina: A Histomorpho logical Review and Mutation Analysis--A Single-Center Study. JLow Genit Tract Dis 19: 350-353. [Crossref]

8. Robboy SJ, Mutter GL, Prat J, Bentley RC, Russell P, et al. (2008) Robboy's Pathology of the Female Reproductive Tract ( $\left.2^{\text {nd }} \mathrm{edn}\right)$. London: Churchill Livingstone.

9. Ditto A, Bogani G, Martinelli F, Di Donato V, Laufer J, et al. (2016) Surgical Management and Prognostic Factors of Vulvovaginal Melanoma. J Low Genit Tract Dis 20: e24-29. [Crossref]

10. Crowson AN, Magro CM, MihmJr MC (2001)The Melanocytic Proliferations: A Comprehensive Textbook of Pigmented Lesions. New Jersey: Wiley-Blackwell.

11. Karney MY, Cassidy MS, Zahn CM, Snyder RR (2001) Melanosis of the vagina. A case report. J Reprod Med 46: 389-391.[Crossref]

12. Tsukada Y (1976) Benignmelanosis of the vagina and cervix. Am J Obstet Gynecol 124 211-212. [Crossref]

13. Lee BS, Yoon TJ, Oh CW, Kim TH (1996) A Case of Vulvar Melanosis. Ann Dermatol 8: 275 .

14. Mannone F, De Giorgi V, Cattaneo A, Massi D, De Magnis A, et al. (2004) Dermoscopic features of mucosal melanosis. Dermatol Surg 30: 1118-1123. [Crossref]

15. Estrada R, Kaufman R (1993) Benign vulvar melanosis. J Reprod Med 38: 5-8. [Crossref]

16. Sison-Torre EQ, Ackerman AB (1985) Melanosis of the vulva. A clinical simulator of malignant melanoma. Am J Dermatopathol 7: 51-60.[Crossref]

17. Lee RB, Buttoni L Jr, Dhru K, Tamimi H (1984) Malignant melanoma of the vagina: a case report of progression from preexistingmelanosis. Gynecol Oncol 19: 238-245. [Crossref]

18. Jones I (2012) Melanosis of the vulva: A long-term follow-up from Brisbane, Australia Open Journal of Obstetrics and Gynaecology 2: 247-249.

19. Núñez-Troconis J, Delgado M, González G, Rivas A, Molero K (2011) Melanosis of the vagina and human papillomavirus infection, an uncommon pathology: case report. Invest Clin 52: 268-273. [Crossref]

20. van Engen-van Grunsven AC, Küsters-Vandevelde HV, De Hullu J, et al. (2014) NRAS mutations are more prevalent than KIT mutations in melanoma of the female urogenita tract--a study of 24 cases from the Netherlands. Gynecol Oncol 134: 10-14. [Crossref]

21. Mert I, Semaan A, Winer I, Morris RT, Ali-Fehmi R (2013) Vulvar/vaginal melanoma an updated surveillance epidemiology and end results database review, comparison with cutaneous melanoma and significance of racial disparities. Int J Gynecol Cancer 23: 1118-1125. [Crossref]

Copyright: (C2016 Kelly D. This is an open-access article distributed under the terms of the Creative Commons Attribution License, which permits unrestricted use, distribution, and reproduction in any medium, provided the original author and source are credited. 